\title{
Morphological and Molecular Screening of Turmeric (Curcuma longa L.) Cultivars for Resistance against Parasitic Nematode, Meloidogyne incognita
}

\author{
Swatilekha Mohanta ${ }^{1}$, Swain $\mathrm{PK}^{1}$, Sial $\mathbf{P}^{1}$ and Rout $\mathrm{GR}^{2 \star}$
}

${ }^{1}$ Department of Nematology, College of Agriculture, OUAT, Regional Research Technology Transfer Station, Pottangi, Bhubaneswar-751003, Odisha, India ${ }^{2}$ Department of Biotechnology, College of Agriculture, OUAT, Bhubaneswar-751003, India

\begin{abstract}
Turmeric (Curcuma longa) is a high value export oriented important commercial crop among the spices. The production was declined due to several biotic and abiotic stresses. Among biotic stresses, root-knot nematode, Meloidogyne incognita is a major threat to turmeric cultivation. Seventy cultivars were screened to identify the resistance to root-knot nematode, Meloidogyne incognita. The result revealed that cultivars 'Dugirala', 'PTS-31', 'Ansitapani', 'PTS-42', 'PTS-47'noted as fully resistant;'361 Gorakhpur', '328 Sugandham', 'PTS-21' rated as moderately resistant and rest other cultivars were susceptible. The cultivar '328 Sugandham' was moderately resistant to root-knot nematode. This was further confirmed through DNA amplification studies with ISSR markers. The similarity matrix was obtained after multivariate analysis using Nei and Li's coefficient and the matrix value was ranged from 0.35 to 0.89 , with a mean value of 0.62 . The two cultivars 'Dugirala' and ' 361 Gorakhpur' with $48 \%$ similarity with other 21 cultivars. Both the cultivars were resistance to root knot nematode (RKN) having indexed ranged from 2.0 to 3.0. The five cultivars i.e. 'Tu No.4', 'Tu No.1', 'Erode local', 'TC-4' and ' 'Phulbani Wild' were 78\% similarity and susceptible to RKN having index from 4.0 to 5.0. Cultivars 'Dugirala', '328 Sugandham' and 'PTS-47' exhibited resistance to both root knot nematodes. This investigation as an understanding of the level and partitioning of genetic variation within the cultivars with resistant/susceptible to root knot nematode disease would provide an important input into determining efficient management strategies for breeding program.
\end{abstract}

Keywords: Meloidogyne incognita; Turmeric; Screening; Resistance; ISSR marker

\section{Introduction}

Turmeric (Curcuma longa), an herbaceous plant is native to tropical south East Asia. It is a high value export oriented important commercial crop among spices in India. The tuber crops represent the most important food commodity in many subtropical and tropical countries [1]. The rhizome has 1.8 to 5.4 percent curcumin, the pigment and 2.5 to 7.2 percent of essential oil. It is used as a dye with varied application in drug and cosmetic industries. In India, it is grown in an area of 104,500 ha producing annually $3,28,800$ tones. Although, India is leading in its production (75\% of world output), the average productivity and quality are not satisfactory for which the export value is reduced dramatically. Annually 18 to 20 crores worth of turmeric are exported. In India, Andhra Pradesh is the leading state followed by Maharashtra, Tamil Nadu, Orissa, Kerala and Bihar. However, the production and productivity of this high value cash crop is declining day by day because of several biotic and abiotic stresses. Among biotic stresses root-knot nematode, Meloidogyne incognita is a major threat to turmeric cultivation [2,3]. Nematodes causes' serious yield performance and quality reduction in most of the tuber crops [4-6]. Root-knot nematodes (Meloidogyne spp), first identified as a potential threat to yam production [7] (Bridge) and also in sweet potato [8]. This extensive polyphagous species is a sedentary endo-parasitic nematode that induces multinucleated modified transfer cells inside the vascular bundles of roots through a series of physiological and biochemical changes thereby resulting in galling root dysfunction, reduced water flow and photosynthesis [9]. Management of this important phytophagous nematode through conventional tactics has become a difficult task because of limited availability of nematicides in the world market as well as environmental concern. Few reports are available on molecular screening on tomato, cotton, peanut with regard to root knot nematode resistance [10-13]. Molecular markers have now come up as the most desirable tool for detecting and characterizing variation among the resistance and susceptible at the DNA level Among the different molecular markers, inter simple sequence repeats (ISSR) techniques have proven to be a reliable, reproducible, easy to generate, inexpensive and versatile set of markers that relies on repeatable amplification of DNA sequences using single primers. Therefore, the present study was undertaken to identify some resistant turmeric cultivars as an ecofriendly alternative to nematicides based on physical markers and to correlate these findings with molecular investigation through ISSR marker assisted DNA amplification studies.

\section{Materials and Methods}

Seventy cultivars of turmeric were collected from Regional Research Technology Transfer Station (RRTTS), Pottangi (Odisha) for screening their resistance against root-knot nematode, Meloidogyne incognita. These cultivars were planted in the 8 " diameter surface sterilized earthen pots containing $3 \mathrm{~kg}$ steam sterilized soil and kept in the experimental garden of the Department of Nematology, College of Agriculture, Orissa University of Agriculture and Technology,

*Corresponding author: Rout GR, Department of Biotechnology, College of Agriculture, OUAT, Bhubaneswar, India, Tel: 0674239 7964; E-mail: grrout@rediffmail.com

Received September 02, 2014; Accepted September 30, 2014; Published October 06, 2014

Citation: Mohanta S, Swain PK, Sial P, Rout GR (2015) Morphological and Molecular Screening of Turmeric (Curcuma longa L.) Cultivars for Resistance against Parasitic Nematode, Meloidogyne incognita. J Plant Pathol Microb 6: 270. doi:10.4172/2157-7471.1000270

Copyright: @ 2015 Mohanta S, et al. This is an open-access article distributed under the terms of the Creative Commons Attribution License, which permits unrestricted use, distribution, and reproduction in any medium, provided the original author and source are credited. 
Citation: Mohanta S, Swain PK, Sial P, Rout GR (2015) Morphological and Molecular Screening of Turmeric (Curcuma longa L.) Cultivars for Resistance against Parasitic Nematode, Meloidogyne incognita. J Plant Pathol Microb 6: 270. doi:10.4172/2157-7471.1000270

Page 2 of 6

Bhubaneswar. One month after the planting freshly hatched second stage juveniles of $M$. incognita were inoculated @ 3000 J2/pot around the root zone of the plant for infection and development. Sixty days after inoculation, the plants in pots were uprooted carefully and roots were evaluated for resistance against $M$. incognita by following 1-5 point scale [14] on the basis of development of galls and egg masses on the root as follow (Table 1).

Data on root-knot indices were subjected to statistical analysis

\begin{tabular}{|c|c|c|c|}
\hline SI. No. & Cultivar & Root-knot Index & Reaction \\
\hline V1 & Dugirala & 2.00 & $\mathrm{R}$ \\
\hline V2 & Tu. No.4 & 4.00 & $\mathrm{~s}$ \\
\hline V3 & Erode local & 4.00 & $\mathrm{~s}$ \\
\hline V4 & PTS-53 & 3.50 & $\mathrm{~S}$ \\
\hline V5 & Sudarsan & 4.50 & HS \\
\hline V6 & PTS-31 & 2.00 & $\mathrm{R}$ \\
\hline V7 & CLS-33 & 5.00 & HS \\
\hline V8 & TC-4 & 3.50 & $\mathrm{~s}$ \\
\hline V9 & Phulbani Wild & 4.00 & $\mathrm{~s}$ \\
\hline V10 & 361 Gorakhpur & 3.00 & MR \\
\hline V11 & Ansitapani & 2.00 & $\mathrm{R}$ \\
\hline V12 & Tu. No.1 & 4.50 & HS \\
\hline V13 & PTS-34 & 4.50 & HS \\
\hline V14 & Bataguda & 4.00 & $\mathrm{~s}$ \\
\hline V15 & PTS-17 & 5.00 & HS \\
\hline V16 & PTS-8 & 4.50 & HS \\
\hline V17 & PTS-42 & 2.00 & $\mathrm{R}$ \\
\hline V18 & Ethamkalam & 5.00 & HS \\
\hline V19 & 328 Sugandham & 2.50 & MR \\
\hline V20 & PTS-47 & 2.00 & $\mathrm{R}$ \\
\hline V21 & PTS-21 & 2.50 & MR \\
\hline V22 & Kasturi Manjari & 4.50 & $\mathrm{HS}$ \\
\hline V23 & PCT-7 & 3.50 & $\mathrm{~s}$ \\
\hline V24 & Black turmeric & 5.00 & HS \\
\hline V25 & Chayapusupu-1 & 5.00 & HS \\
\hline V26 & CAS-15 & 5.00 & HS \\
\hline V27 & CAS- 51 & 5.00 & HS \\
\hline V28 & CAS- 53 & 5.00 & HS \\
\hline V29 & CLS-3 & 3.50 & $\mathrm{~s}$ \\
\hline V30 & CLS-21 & 5.00 & HS \\
\hline V31 & Florescent & 4.00 & $\mathrm{~s}$ \\
\hline V32 & GL-Puram & 5.00 & HS \\
\hline V33 & Kuchipudi & 4.00 & $\mathrm{~s}$ \\
\hline V34 & K. Local & 5.00 & HS \\
\hline V35 & Lakadong & 4.00 & $\mathrm{~s}$ \\
\hline V36 & Mydukur & 4.00 & s \\
\hline V37 & Mundapadar & 5.00 & HS \\
\hline SI. No. & Cultivar & Root-knot Index & Reaction \\
\hline V38 & NB-60 & 5.00 & HS \\
\hline V39 & NB-6206 & 5.00 & HS \\
\hline V40 & No.38 & 4.00 & $\mathrm{~S}$ \\
\hline V41 & РCT-9 & 5.00 & HS \\
\hline V42 & PTS-1 & 4.00 & $\mathrm{~s}$ \\
\hline V43 & PTS-20 & 4.00 & S \\
\hline V44 & PTS-3 & 5.00 & HS \\
\hline V45 & PTS-4 & 4.00 & $\mathrm{~s}$ \\
\hline V46 & PTS-11 & 5.00 & HS \\
\hline V47 & PTS-12 & 4.00 & $\mathrm{~s}$ \\
\hline
\end{tabular}

\begin{tabular}{|c|c|c|c|}
\hline V48 & PTS-13 & 4.00 & $S$ \\
\hline V49 & PTS-27 & 4.50 & $\mathrm{~S}$ \\
\hline V50 & PTS-30 & 4.00 & $S$ \\
\hline V51 & PTS-33 & 5.00 & $\mathrm{HS}$ \\
\hline V52 & PTS-43 & 4.00 & S \\
\hline V53 & PTS-44 & 5.00 & $\mathrm{HS}$ \\
\hline V54 & PTS-48 & 4.00 & $S$ \\
\hline V55 & PTS-50 & 5.00 & $\mathrm{HS}$ \\
\hline V56 & PTS-51 & 5.00 & $\mathrm{HS}$ \\
\hline V57 & PTS-54 & 4.00 & $S$ \\
\hline V58 & PTS-55 & 5.00 & $\mathrm{HS}$ \\
\hline V59 & PTS-57 & 4.00 & $S$ \\
\hline V60 & PTS-62 & 5.00 & $\mathrm{HS}$ \\
\hline V61 & Rajpuri local & 5.00 & $\mathrm{HS}$ \\
\hline V62 & Rajendra Sonia & 5.00 & $\mathrm{HS}$ \\
\hline V63 & Ranga & 5.00 & $\mathrm{HS}$ \\
\hline V64 & Raikia & 5.00 & $\mathrm{HS}$ \\
\hline V65 & Roma & 5.00 & $\mathrm{HS}$ \\
\hline V66 & Surama & 5.00 & $\mathrm{HS}$ \\
\hline V67 & Tu. No.-6 & 5.00 & $\mathrm{HS}$ \\
\hline V68 & VK-9 & 5.00 & $\mathrm{HS}$ \\
\hline V69 & VK-154 & 4.00 & $S$ \\
\hline \multirow[t]{5}{*}{ V70 } & Wynad local & 5.00 & $\mathrm{HS}$ \\
\hline & Mean & 4.27 & \\
\hline & Sem $(0.05)$ & 0.21 & \\
\hline & $\mathrm{CD}(0.05)$ & 0.58 & \\
\hline & $\mathrm{CV}$ & 6.85 & \\
\hline
\end{tabular}

R: Resistance, MR: Moderate Resistance, S: Susceptible, HS: Highly Susceptible.

Table 1: Screening of turmeric cultivars against $M$. incognita.

by following analysis of variance through complete randomized block design. Leaf samples of selected resistant, moderately resistant, susceptible and highly susceptible cultivars were collected for DNA extraction and amplification by ISSR marker and these selected cultivars were planted in raised beds $(1 \mathrm{~m} \times 3 \mathrm{~m})$ at RRTTS, Pottangi with three replications. Yield was recorded after fully maturation of the cultivars. Data were subjected to statistical analysis through analysis of variance in a randomized block design. The results of the pot culture studies are pertaining to resistance by $M$. incognita, plant growth and yield were correlated to confirm the resistance based on morphological features with that of molecular investigation.

\section{Genomic DNA extraction and quantification}

DNA was extracted from fresh leaves using the cetyl-trimethyl ammonium bromide (CTAB) method [15,16]. Approx. $200 \mathrm{mg}$ of fresh leaves were ground to a powder in liquid nitrogen using a mortar and pestle. The powder was transferred to a $50-\mathrm{ml}$ falcon tube with $10 \mathrm{ml}$ of CTAB buffer [ $2 \%$ (w/v) CTAB, $1.4 \mathrm{M} \mathrm{NaCl}, 20 \mathrm{mM}$ EDTA, $100 \mathrm{mM}$ Tris (tris(hydroxymethyl) amino methane)-HCl, $\mathrm{pH} \mathrm{8.0,}$ and $0.2 \%(\mathrm{v} / \mathrm{v}) \beta$-mercaptoethanol. The homogenate was incubated at $60^{\circ} \mathrm{C}$ for $2 \mathrm{~h}$, extracted with an equal volume of chloroform/isoamyl alcohol $(24: 1, \mathrm{v} / \mathrm{v})$, and centrifuged at $9838 \times g$ for $20 \mathrm{~min}$. DNA was precipitated from the aqueous phase by mixing it with unequal volume of isopropanol. After centrifugation at $9838 \times g$ for $10 \mathrm{~min}$, the resultant DNA pellet was washed with $70 \%(\mathrm{v} / \mathrm{v})$ ethanol, air-dried, and re-suspended in TE (10 mM Tris- $\mathrm{HCl}, \mathrm{pH} 8.0$, and $0.1 \mathrm{mM}$ EDTA) buffer. DNA quantifications were performed by visualizing under UV light, after electrophoresis on $0.8 \%(\mathrm{w} / \mathrm{v})$ agarose gel at $50 \mathrm{~V}$ for 45 min and comparing with a known amount of lambda DNA marker 
Citation: Mohanta S, Swain PK, Sial P, Rout GR (2015) Morphological and Molecular Screening of Turmeric (Curcuma longa L.) Cultivars for Resistance against Parasitic Nematode, Meloidogyne incognita. J Plant Pathol Microb 6: 270. doi:10.4172/2157-7471.1000270

(Emerk Bioscience, India). The resuspended DNA was then diluted in TE buffer to $5 \mu \mathrm{g} / \mu \mathrm{l}$ concentration for use in polymerase chain reaction (PCR).

\section{Primer screening}

Twenty synthesized inter simple sequence repeat(ISSR) primers (M/S Emerk Bioscience, Bangalore, India) were initially screened to determine the suitability of each primer for the study. Primers were selected for further analysis based on their ability to detect distinct, clearly resolved, and polymorphic amplified products within the varieties. To ensure reproducibility, the primers generating no, weak, or complex patterns were discarded.

\section{ISSR assay}

PCRs with a single primer were carried out in a final volume of $25 \mu \mathrm{l}$ containing $20 \mathrm{ng}$ template DNA, $100 \mu \mathrm{M}$ of each deoxyribonucleotide triphosphate, $20 \mathrm{ng}$ of oligonucleotides synthesized primer $(\mathrm{M} / \mathrm{S}$ Bangalore Genei, Bangalore, India), $1.5 \mathrm{mM} \mathrm{MgCl}_{2}$, $1 \mathrm{X}$ Taq buffer (10 $\mathrm{mM}$ Tris- $\mathrm{HCl}, \mathrm{pH} 9.0,50 \mathrm{mM} \mathrm{KCl}, 0.001 \%$ gelatin), and $0.5 \mathrm{U}$ Taq DNA polymerase (M/S Emerk Bioscience, India). Amplification was performed in a thermal cycler (Peqlab, United Kingdom) programmed for a preliminary $2 \mathrm{~min}$ denaturation step at $94^{\circ} \mathrm{C}$, followed by 40 cycles of denaturation at $94^{\circ} \mathrm{C}$ for 20 s, annealing at required temperature for $30 \mathrm{~s}$, extension at $72^{\circ} \mathrm{C}$ for $1 \mathrm{~min}$, and finally amplification at $72^{\circ} \mathrm{C}$ for $10 \mathrm{~min}$. Amplification products were separated alongside a molecular weight marker $(3.0 \mathrm{~Kb}$ plus ladder, $\mathrm{M} / \mathrm{S}$ Emerk Bioscience, India) by $1.5 \%(\mathrm{w} / \mathrm{v})$ agarose gel. Electrophoresis in $1 \mathrm{X}$ TAE (Tris acetate/ EDTA) buffer. The gel was prestained with ethidium bromide and visualized under UV light. Gel photographs were scanned through a Gel Documentation System (Gel Doc., UVITECH, UK), and the amplification product sizes were evaluated using the software Quantity one (Bio-Rad) (Rohlf).

\section{Data analysis}

During data analysis, only reproducible polymorphic bands in amplification reactions were considered as present. Each band was treated as a separate putative locus, and scored as present (1) or absent (0) in each cultivar. The binary data of the ISSR fingerprints were used further for population genetic analyses. The numbers of monomorphic and polymorphic bands were derived from the binary data, and their percentages were calculated

Bands with similar mobility to those detected in the negative control, if any, were not scored. Similarity index was estimated using the formula, $S=2 \mathrm{~N}_{A B} / \mathrm{N}_{A}+\mathrm{N}_{B}$ [17]

Where, $\mathrm{N}_{\mathrm{AB}}$ is the number of amplified products common to both $\mathrm{A}$ and $\mathrm{B}$.

\section{Results and Discussion}

The screening of seventy cultivars against the $M$. incognita on the basis of varying degree of galling in the plant roots as indicated by root-knot indices. None of the seventy tested cultivars reacted highly resistant to $M$. incognita (Table 1). The root-knot indices of all the cultivars ranged between 2.0-5.0. Statistical analysis of data indicated that there were significant differences among the cultivars. 'Dugirala', 'PTS-31', 'Ansitapani', 'PTS-42' and 'PTS-47' with root-knot index 2.0 and resistant to $M$. incognita, which were significantly different from other cultivars. The root knot indices of cultivars '361-Gorakhpur', '328-Sugandham' and 'PTS-21' were 3.0, 2.5 and 2.5 respectively and rated as moderately resistant. Rest other cultivars were susceptible to highly susceptible to root-knot indices ranging between 4.0-5.0. Eapen et al. [18] reported that cultivars like 'Erode', 'Cls. No.4' were rated as highly resistant and 'C 11.320 ', 'Kattapana', 'Cls. No.21' as a moderate resistant to $M$. incognita. In the present study, the cultivar 'Dugirala' showed resistance to nematode which was conformity with Mani et al. [19]. There were significant differences among the cultivars on the basis of plant growth, yield performance and root-knot indices. 'PTS-21' rated moderately resistant to $M$. incognita has shown highest plant height, leaf length, leaf width and rhizome yield. The rest two moderately resistant cultivars '361-Gorakhpur' and '328-Sugandham' have shown moderate plant growth and rhizome yield. Some of the cultivars resistant to $M$. incognita exhibited moderate to low plant growth, rhizome yield and low root-knot indices. Among these, 'PTS$47^{\prime}\left(6.9 \mathrm{Kg} / 3 \mathrm{~m}^{2}\right)$ was the highest yielder followed by 'PTS-42' (6.46 $\left.\mathrm{Kg} / 3 \mathrm{~m}^{2}\right)$. The cultivars like '361-Gorakhpur' and 'PTS-21'exhibiting moderately resistant and the cultivars like 'Ansitapani' and'PTS-42' exhibiting resistant to $M$. incognita. Similarly, cultivars like 'Erode local', 'PTS-53', 'Sudarsan', 'CLS-33', 'Phulbani Wild', 'PTS-17' and 'Kasturi Manjari' were susceptible to M. incognita. Two cultivars 'Dugirala' and 'PTS-47' were found resistant to M. incognita.

On the basis of root-knot indices, out of seventy cultivars, 23 cultivars were selected to compare the resistance, moderate resistance, susceptible and highly susceptible on the basis of ISSR markers. The present study offers an optimization of primer screening for evaluation of genetic relationship among twenty three cultivars of Curcuma longa through ISSR analysis (Table 2). The cultivar 'PTS-53' was used initially for screening of synthesis primers for amplification by using polymerase chain reactions. The results showed some primers produced relatively more amplification fragments compared to other primers. The reproducibility of the amplification product was tested on DNA from three independent extractions of the cultivars. Most of the amplification reactions were duplicated. Only bands that were consistently reproduced across amplifications were considered for the analysis. Bands with the same mobility were considered as identical fragments, receiving equal values, regardless of their staining intensity. When multiple bands in a region were difficult to resolve, data for that region of the gel was not included in the analysis. Among the twenty primers tested, only eleven of them produced unambiguous DNA fragments. All the twenty three cultivars of Curcuma longa extensively amplified using these eleven ISSR primers (Table 3) and produced 66 fragments ranging from $100 \mathrm{bp}$ to $2500 \mathrm{bp}$. The minimum size fragment of $100 \mathrm{bp}$ was amplified by the primer USB-835 and the maximum size fragment of $2500 \mathrm{bp}$ was amplified by primer USB-807, USB-708, USB-810, and USB-837 and USB-840. Out of 66 fragments, only 50 fragments (75\%) were polymorphic. The pattern of ISSR produced by the primers USB-810, USB-841, USB-807 and USB- 835 are shown in Figure 1 . The genetic variation through molecular markers has been highlighted in a number of medicinal plants [2,20-22]. The present results have shown the narrow variation within some of the cultivars. The similarity matrix was obtained after multivariate analysis using Nei and Li's coefficient and is presented in Table 4 . The matrix value was ranged from 0.35 to 0.89 , with a mean value of 0.62 . The high matrix values indicated that there were distantly related to each other. The similarity matrix obtained in the present study was used to construct a dendrogram with the unweight UPGMA method and resulted in their distant clustering in the dendrogram (Figure 2). The dendrogram shows two major clusters. The first major cluster (A) had only two cultivars 'Dugirala' and ' 361 Gorakhpur' with $48 \%$ similarity with other major cluster (B) having 21 cultivars. Both the cultivars of major cluster -1 were resistance to root knot nematode (RKN) having indexed ranged 
Citation: Mohanta S, Swain PK, Sial P, Rout GR (2015) Morphological and Molecular Screening of Turmeric (Curcuma longa L.) Cultivars for Resistance against Parasitic Nematode, Meloidogyne incognita. J Plant Pathol Microb 6: 270. doi:10.4172/2157-7471.1000270

Page 4 of 6

\begin{tabular}{|c|c|c|c|c|c|c|c|c|c|c|}
\hline SI. No. & $\begin{array}{l}\text { Turmeric } \\
\text { cultivars }\end{array}$ & $\begin{array}{l}\text { Plant Ht. } \\
\text { (cm) }\end{array}$ & Leaves/Tiller & Tillers/Plant & $\begin{array}{l}\text { Leaf Length } \\
\quad(\mathrm{cm})\end{array}$ & $\begin{array}{l}\text { Leaf Width } \\
\quad(\mathrm{cm})\end{array}$ & $\begin{array}{c}\text { Yield of fresh } \\
\text { rhizome } \\
\left(\mathrm{kg} / \mathrm{mm}^{2}\right)\end{array}$ & $\begin{array}{l}\text { Root-knot } \\
\text { Index }\end{array}$ & $\begin{array}{l}\text { Reaction to } \\
\text { Root-knot } \\
\text { nematode }\end{array}$ & $\begin{array}{c}\text { Reaction to } \\
\text { Taphrina leaf } \\
\text { blotch }\end{array}$ \\
\hline V1 & Dugirala & 87.8 & 6.6 & 3.4 & 42.4 & 9.7 & 2.1 & 2.00 & $\mathrm{R}$ & $\mathrm{R}$ \\
\hline V2 & Tu. No.4 & 102.4 & 6.2 & 3.2 & 50.4 & 11.2 & 8.6 & 4.00 & $\mathrm{~s}$ & HS \\
\hline V3 & Erode local & 96.4 & 6.2 & 3 & 46.8 & 10.8 & 8.5 & 4.00 & $S$ & $\mathrm{R}$ \\
\hline V4 & PTS-53 & 82.8 & 6.8 & 3 & 41 & 12.5 & 6.9 & 3.50 & $S$ & $\mathrm{R}$ \\
\hline V5 & Sudarsan & 76.8 & 7.2 & 2.2 & 36.8 & 13 & 2.9 & 4.50 & HS & $\mathrm{R}$ \\
\hline V6 & PTS-31 & 87.2 & 6.4 & 3.2 & 25 & 10.7 & 1.8 & 2.00 & $\mathrm{R}$ & $S$ \\
\hline V7 & CLS-33 & 73.4 & 6 & 1.6 & 36.6 & 11.4 & 5 & 5.00 & $\mathrm{HS}$ & $\mathrm{R}$ \\
\hline V8 & TC-4 & 71.4 & 6.8 & 2.4 & 37.4 & 11.4 & 5.4 & 3.50 & $S$ & $S$ \\
\hline V9 & Phulbani Wild & 72.8 & 5.6 & 3.4 & 38 & 8.9 & 3.8 & 4.00 & $S$ & $\mathrm{R}$ \\
\hline V10 & $\begin{array}{c}361 \\
\text { Gorakhpur }\end{array}$ & 78.6 & 6 & 1.8 & 37.6 & 10.9 & 7.2 & 3.00 & MR & $S$ \\
\hline V11 & Ansitapani & 87.6 & 5.6 & 3.4 & 46.2 & 11.8 & 5.4 & 2.00 & $\mathrm{R}$ & $\mathrm{s}$ \\
\hline V12 & Tu. No.1 & 83 & 6 & 2.2 & 40.2 & 12.9 & 6.7 & 4.50 & HS & HS \\
\hline V13 & PTS-34 & 82.2 & 5.8 & 3.2 & 43.4 & 12.9 & 4.6 & 4.50 & HS & HS \\
\hline V14 & Bataguda & 84 & 6 & 2.8 & 39.6 & 12 & 8.5 & 4.00 & $S$ & $S$ \\
\hline V15 & PTS-17 & 92.4 & 6.4 & 2 & 44.4 & 11.4 & 6.5 & 5.00 & HS & $\mathrm{R}$ \\
\hline V16 & PTS-8 & 96.6 & 6.2 & 3.2 & 51.6 & 13.4 & 4.1 & 4.50 & HS & HS \\
\hline V17 & PTS-42 & 73.8 & 6.2 & 2.6 & 35.2 & 10.4 & 6.4 & 2.00 & $\mathrm{R}$ & HS \\
\hline V18 & Ethamkalam & 80.2 & 6.8 & 3 & 43.6 & 9.7 & 2.2 & 5.00 & HS & $S$ \\
\hline V19 & $\begin{array}{c}328 \\
\text { Sugandham }\end{array}$ & 92 & 5.8 & 2.8 & 45.2 & 12.5 & 5.9 & 2.50 & MR & $\mathrm{R}$ \\
\hline V20 & PTS-47 & 89.8 & 6.4 & 2.8 & 42.6 & 13.2 & 6.9 & 2.00 & $\mathrm{R}$ & $\mathrm{R}$ \\
\hline V21 & PTS-21 & 121.8 & 6.6 & 2.2 & 60.6 & 13.8 & 12.3 & 2.50 & MR & HS \\
\hline V22 & $\begin{array}{l}\text { Kasturi } \\
\text { Manjari }\end{array}$ & 85.4 & 5.2 & 3 & 43.4 & 11.8 & 5 & 4.50 & HS & $\mathrm{R}$ \\
\hline \multirow[t]{5}{*}{ V23 } & РCT-7 & 90.8 & 5.2 & 3.2 & 49.6 & 12.7 & 4.9 & 3.50 & HS & $S$ \\
\hline & Sem $(0.05)$ & 0.49 & 0.29 & 0.10 & 0.46 & 0.30 & 0.15 & 0.33 & & \\
\hline & $\mathrm{CD}(0.05)$ & 1.45 & 0.85 & 0.30 & 1.35 & 0.89 & 0.43 & 0.96 & & \\
\hline & $\mathrm{CV}$ & 0.99 & 8.1 & 6.45 & 1.88 & 4.51 & 4.49 & 13.08 & & \\
\hline & Mean & 86.5 & 6.17 & 2.76 & 42.5 & 11.7 & 5.72 & 3.57 & & \\
\hline
\end{tabular}

R: Resistance, MR: Moderate Resistance, S: Susceptible, HS: Highly Susceptible

Table 2: Morphological characteristics of 23 cultivars of C.longa and reaction of turmeric cultivars to M. incognita and T. maculans.

\begin{tabular}{|c|c|c|c|c|}
\hline Name of Primer & Sequence of the primer & $\begin{array}{l}\text { Total No. amplification } \\
\text { products }\end{array}$ & $\begin{array}{l}\text { No. of polymorphic } \\
\text { products }\end{array}$ & Size range $(\mathrm{Kb})$ \\
\hline USB-807 & 5'-AGAGAGAGAGAGAGAGT-3' & 07 & 07 & $200-2500$ \\
\hline USB-808 & 5'- AGAGAGAGAGAGAGAGC-3' & 07 & 06 & $100-2500$ \\
\hline USB-810 & 5'-GAGAGAGAGAGAGAGAT -3' & 06 & 05 & $600-2500$ \\
\hline USB-811 & 5'-GAGAGAGAGAGAGAGAC-3' & 05 & 04 & $200-2000$ \\
\hline USB-815 & 5'-СТСТСТСТСТСТСТСТG-3' & 07 & 05 & $200-1500$ \\
\hline USB-835 & 5'-AGAGAGAGAGAGAGAGTC-3' & 04 & 01 & $500-1500$ \\
\hline USB-836 & 5'-AGAGAGAGAGAGAGAGT-3' & 06 & 06 & $200-2000$ \\
\hline USB-837 & 5'-AGAGAGAGAGAGAGAGCC-3' & 07 & 05 & $500-2500$ \\
\hline USB-840 & 5'-GAGAGAGAGAGAGAGACTT-3' & 06 & 03 & $200-2500$ \\
\hline USB-841 & 5'-GAGAGAGAGAGAGAGACTC-3' & 05 & 02 & $500-1500$ \\
\hline USB-842 & 5'-AGAGAGAGAGAGAGAGCA-3' & 06 & 06 & $500-2000$ \\
\hline
\end{tabular}

Table 3: Total number of amplified fragments and number of polymorphic bands generated by PCR using selected ISSR primers in 23 cultivars of Curcuma longa.

from 2.0 to 3.0. Second major cluster (B) having 21 cultivars and again divided into two minor clusters (B1 and B2). One minor cluster (B1) having five cultivars i.e. 'Tu No.4', 'Tu No.1', 'Erode local', 'TC-4' and 'Phulbani Wild'. Among the five cultivars, two cultivars i.e. 'Tu No.4', 'Tu No.1' were making one group with $78 \%$ similarity and susceptible to RKN having index from 4.0 to 5.0. Another cultivar 'Erode local' making one group with $71 \%$ similarity with other two cultivars were also susceptible to RKN. Second minor cluster (B2) again subdivided into two sub-minor clusters i.e. $\mathrm{C} 1$ and $\mathrm{C} 2$. First sub-minor cluster $(\mathrm{C} 1)$ having 4 cultivars with $63 \%$ similarity and all are highly susceptible to
RKN. Second sub-minor cluster (C2) having 12 cultivars and making two groups. One group having two cultivars ('Ansitapami' and 'PST31 ') with $75 \%$ similarity and other group having 10 cultivars with $89 \%$ similarity. The cultivars 'PTS-21', '328 Sugandham','PTS-42' and 'PTS-47' were resistance to RKN with root knot indices ranged from 2.0 -2.50. Chu et al. [12] identified RAPD based markers to select for nematode resistance in Arachis hypogaea. In another study, Tahery [23] revealed that the identification of ISSR markers associated with root knot nematode resistance of Hibiscus cannabinus. He found 13 polymorphic ISSR markers between the resistant and susceptible 
Citation: Mohanta S, Swain PK, Sial P, Rout GR (2015) Morphological and Molecular Screening of Turmeric (Curcuma longa L.) Cultivars for Resistance against Parasitic Nematode, Meloidogyne incognita. J Plant Pathol Microb 6: 270. doi:10.4172/2157-7471.1000270

Page 5 of 6
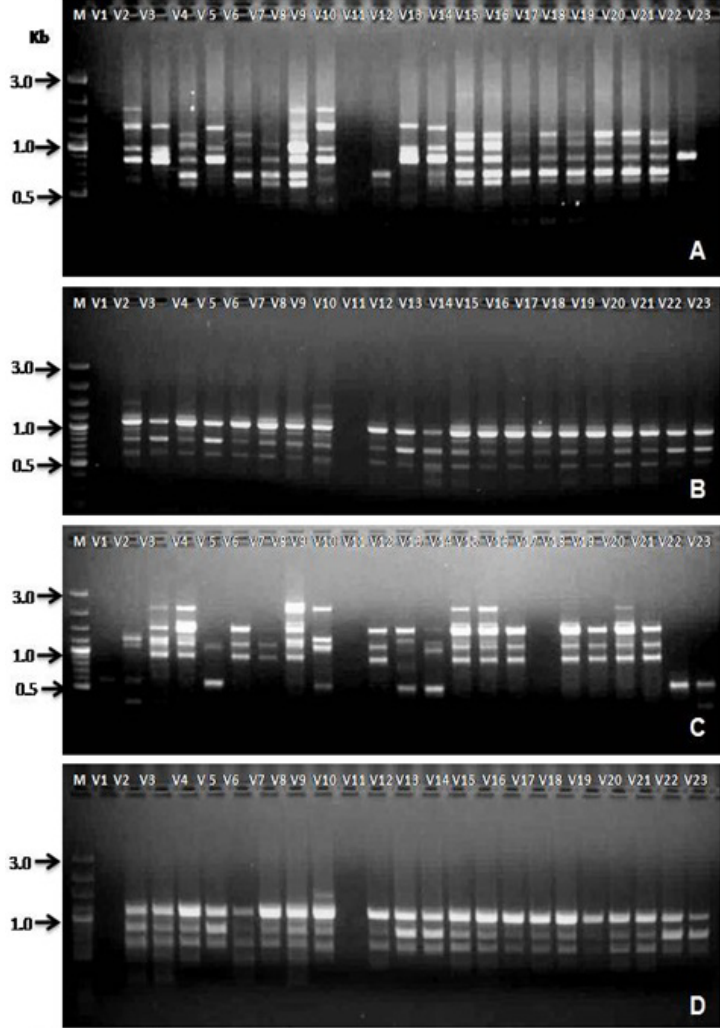

Figure 1: ISSR patterns of 23 varieties of Curcurma longa generated by primer USB-810(A), USB-841 (B), USB-807(C) and USB-835(D) MKb molecular weight ladder, V1-V23 assigned as cultivars indicated in Table 2.

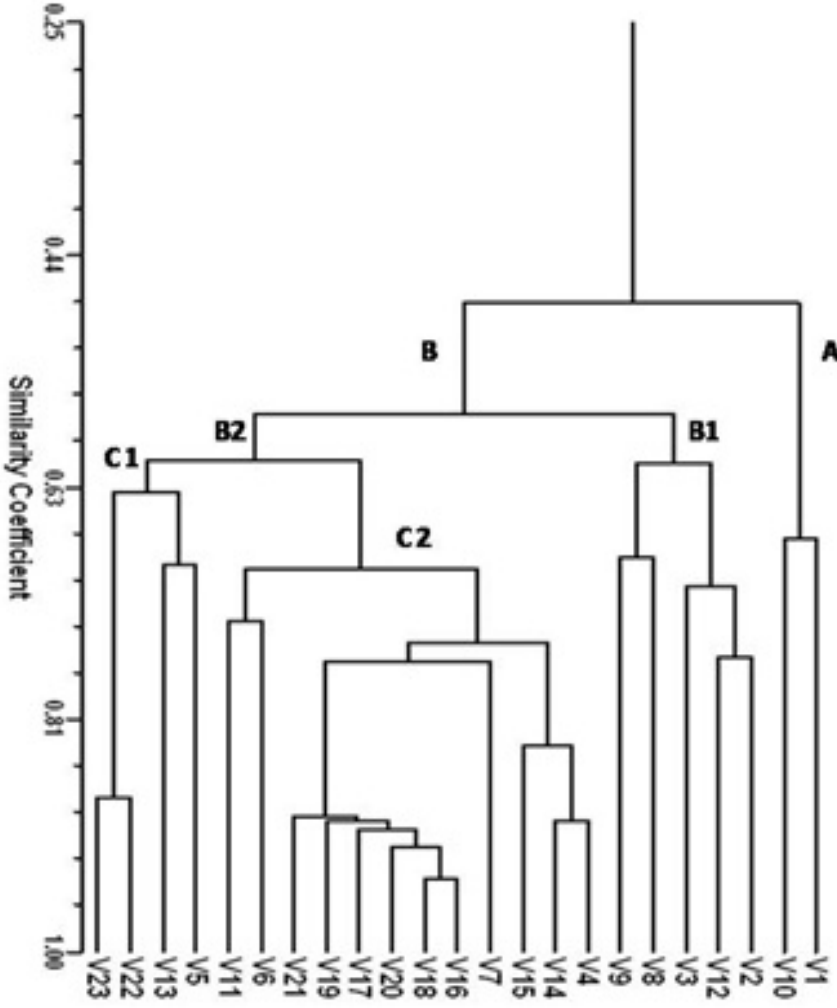

Figure 2: UPGMA dendrogram showing the genetic relationships 23 varieties of Curcurma longa. V1-V23 assigned as cultivars indicated in Table 2.

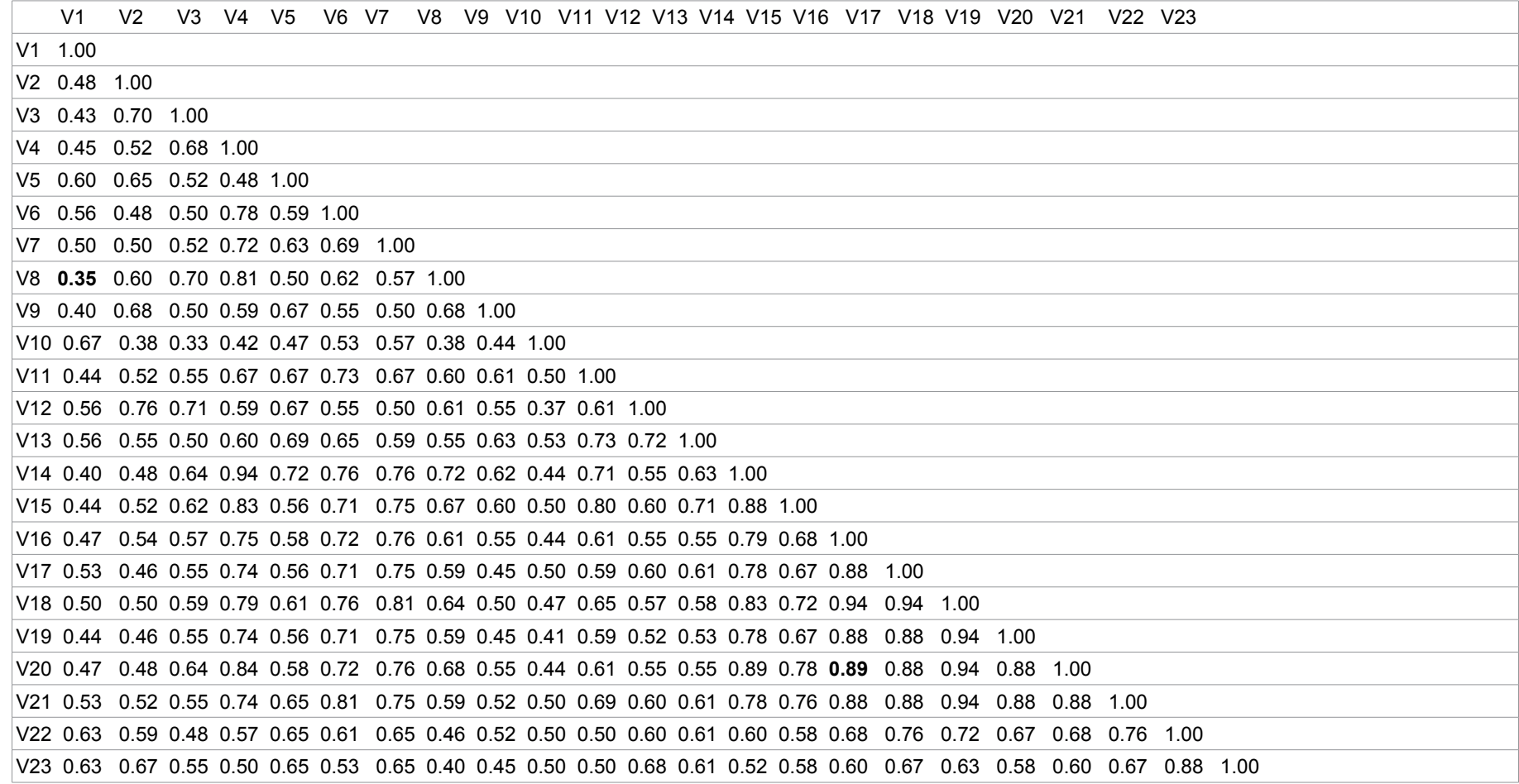

Table 4: Similarity matrix for Nei and Li's coefficient of a total of twenty three variety of turmeric. V1-V23 assigned as name of the cultivars indicated in Table 2. 
Citation: Mohanta S, Swain PK, Sial P, Rout GR (2015) Morphological and Molecular Screening of Turmeric (Curcuma longa L.) Cultivars for Resistance against Parasitic Nematode, Meloidogyne incognita. J Plant Pathol Microb 6: 270. doi:10.4172/2157-7471.1000270

parents. The marker analysis showed that the ISSR primers were significantly associated with the root knot nematode gall index. Jenkins et al. [10] identified SSR markers for marker assisted selection of rootknot nematode resistant to cotton. They found that the chromosome 11 and 14 of cotton genotype have been associated with root knot nematode resistance which opening the way for marker assisted selection in applied breeding. This investigation as an understanding of the level and partitioning of genetic variation within the cultivars with resistant/susceptible to root knot nematode disease would provide an important input into determining efficient management strategies [24]. The genetic variability in a gene pool is normally considered as the major resource for turmeric improvement program.

\section{Acknowledgement}

The authors wish to acknowledge to Department of Agril. Biotechnology, College of Agriculture, Bhubaneswar for providing laboratory facility.

\section{References}

1. Food and Agriculture Organization (2001) Production year book for 2000. FAO Rome.

2. Bai H, Sheela MS, Jiji T (1995) Nemic association and avoidable yield loss in turmeric, Curcuma longa L. Pest Management in Horticultural Ecosystems. 1: 105-110.

3. Ray S, Mohanty KC, Mahapatra SN, Patanaik PR, Ray P (1995) Yield loss in ginger (Zingiber officinale Rosc.) and turmeric (Curcuma longa L.) due to root knot nematode (Melodogyne incognita). JOSAC, 4: 67-69.

4. Caveness FE, Wilson JE, Terry R (1981) Root-knot nematodes on tannia (Xanthosoma sagitifolium).Nematologia Mediterranea, 9: 201-203.

5. McSorley R, O'Hair SK, Parrado JL (1983) Nematodes of cassava, Manihot esculenta Cranz. Nematropica, 13: 262-264.

6. Coyne DL (1994) Nematode parasites of cassava. African Crop Science Journal 2: 355-359.

7. Bridge J (1973) Nematode as pests of yams in Nigeria. Mededelingen Faculteit Landbouwwetenschappen Ghent 38: 841-852.

8. Gapasin RM, Valdez RB, Mendoza EMT (1988) Phenolic involvement in sweet potato resistance to Meloidogyne incognita and M. javanica. Annals of Tropical Research 10: 63-72.

9. Mohanta S, Swain PK, Mishra BK (2013) Root-knot nematode induced physiological and biochemical changes in turmeric under enhanced $\mathrm{CO} 2$ gradient. Journal of Plant Protection and Environment, 10: 74-77.

10. Jenkins JN, McCarty JC, Wubben M., Hayes R, Gutierrez OA, et al. (2012)
SSR markers for marker assisted selection of root-knot nematode (M.incognita) resistant plants in cotton (Gossypium hirsutum L.). Euphytica, 183: 49-54.

11. Danso Y, Akromah R, Osei K (2011) Molecular marker screening of tomato (Solanum lycopersicum L.) germplasms for root knot nematodes (Meloidogyne species) resistance. AJB, 10: 1511-1515.

12. ChuY, Holbrook CC, Timper P, Ozias-Akins P (2007) Development of a PCR based molecular marker to select for nematode resistance in Peanut. Crop Sci., 47: 841-845.

13. Skupinova S, Vejli P, Sedlaki P, Bardovai M, Srbek L, et al. (2004) Using DNA markers for characterization of tomato resistance against root nematode Meloidogyne incognita. Plant Soil, Environment 50: 59-64.

14. Adegbite AA, Amusa NA, Agbaje GO, Taiwo LB (2005) Screening of cowpea varieties for resistance to root-knot nematode under field conditions. Nematropica 35: 155-159.

15. Bai D, Brandle J, Reeleder R (1997) Genetic diversity in North American ginseng (Panax quinquefolius L.) grown in Ontario detected by RAPD analysis. Genome 40: 111-115.

16. Doyle JJ, Doyle JL (1990) Isolation of plant DNA from fresh tissue. Focus, 12 13-15

17. Nei M, Li WH (1979) Mathematical model for studying genetic variation in terms of restriction endonucleases. ProcNatlAcadSci., USA76: 5269-5273

18. Eapen SJ, Ramana KV, Sasi Kumar B, George JK (1998) Resistant to Meloidogyne incognita in ginger and turmeric germplasms. Proceedings of national symposium on rational approaches in nematode management for sustainable agriculture, Anand, India, 22-25 November: 106-109.

19. Mani A, Naidu PH, Madhavachari S (1987) Occurrence and control of Meloidogyne incognita on turmeric in Andhra Pradesh, India. International Nematology Network Newsletter, 4: 13-18.

20. Williams JG, Kubelik AR, Livak KJ, Rafalski JA, Tingey SV (1990) DNA polymorphisms amplified by arbitrary primers are useful as genetic markers. Nucleic Acids Res 18: 6531-6535.

21. Rout GR, Das P, Goel S, Raina SN (1998) Determination of genetic stability of micropropagated plants of ginger using Random Amplified Polymorphic DNA (RAPD) markers. Bot.Bull. Acad. Sin.,39: 23-27

22. Rohlf FJ (1995) NTSYS-PC-Numerical Taxonomy and Multivariate Analysis System, Version 2.0, Exter Software,Setauket, New York, USA

23. Tahery $Y$ (2012) Identification of ISSR markers associated with root knot nematode resistance of Hibiscus cannabinus. Annals of Biological Research, 3: 259-269.

24. Rout GR (2006) Identification of Tinospora cordifolia (Willd.) Miers ex Hook F \& Thomas using RAPD markers.Z Naturforsch C 61: 118-122. 